\title{
THE EXPANSION OF Merremia peltata (L.) Mernill IN FRAGMENTED FOREST OF BUKIT BARISAN SELATAN NATIONAL PARK ENHANCED BY ITS ECOPHYSIOLOGICAL ATTRIBUTES
}

\author{
YANSEN*, WIRYONO, DESELINA, MUHAMMAD F. HIDAYAT and EFRATENTA K. DEPARI \\ Department of Fonestry, Univesityof Bengkulu, Bengkulu, Indonesia
}

Received 28 November 2013/ Accepted 28 September 2014

\begin{abstract}
Forest opening and fragmentation may affect the composition of vegetation by permitting the expansion or domination of one or two species in the area. This study found that Meremia pdtata, an invasive climbing/ creeping species, has dominated some area of Bukit Barisan Selatan National Park (BBSNP). D omination of this species was favoured by forest fragmentation, indicated by the significantly highernumber of individuals of $\mathrm{M}$. pdtatain the open area than in intact forest. The ecophysiological characters of $\mathrm{M}$ pdtatasupport the ability of this species to become a strong invader. As the expansion of this species may negatively affect the biodiversity and vegetation health, the application of appropriate ecological approaches to control the domination of $\mathrm{M}$ pdtatain the conservation area is necessary.
\end{abstract}

Keywords: ecophysiology, forest fragmentation, Mereeriapdtata, population size

\section{INTRODUCTION}

The abundance of species in an area is a fundamental ecological parameter and a critical consideration in decision making for conservation (He \& $\mathrm{G}$ aston 2000). On a geographic scale, one species might be abundant in one region but rare in other regions (Brown 1984). Unlike temperate forests, where a single factor may drive abundance and distribution of species (He \&al. 1997), many underlying factors control these patterns in tropical rainforest ecosystems. Some of those factors are intra and interspecific competition, predation, niche differentiation, disturbances and stochastic recruitment (Janzen 1970; Connell 1978; D enslow 1987).

D isturbances may stimulate the regeneration in the tropical rainforest. The falling of large individual or group of trees is the most common cause of natural gap formation. This will create an open area inside the forest, which has different microclimate, particularly light intensity, from the surrounding shaded areas. This opening will allow

\footnotetext{
* Corresponding author : y.yansen@ymail.com
}

more light reaching the forest floor stimulating seed germination and seedling establishment. Many rainforest species of seedlings need more light to grow faster. However, large scale disturbances may negatively affect plant communities. Ecosystem disturbances are important in changing the dynamic of species competition and may increase the opportunity of certain species to invade the ecosystem. However, the success of alien or local species to dominate one area is influenced by their biological attributes, environmental characteristic of the invaded area and biotic interaction with earlier communities, including interspecific competition (Vila \& Weiner 2004).

In the forest area, ecosystem disturbances may negatively affect the composition of vegetation by permitting the expansion or domination of one or two species in the area. Biological invasion by invasive species is one of the major environmental problems which could threaten biodiversity, affect forest vegetation health and in the long term it could reduce the ability of forest to absorb carbon (Vila \& Weiner 2004; Clavero \& Garcia-Berthou 2005; Master \& al. 2013). 
Thus, if invasive species invade a large area of forests, the ability of forest ecosystem to mitigate climate change may also be affected. $\mathrm{O}$ the other hand, invasive species may be better adapted to the temperature rise (Hellman etal. 2008).

Meremia pdtata(L.) Merrill (Convolvilaceae) is a climbing/ creeping plant that originally comes from the Pacific. This species has been reported to become invasive in many areas of the Pacific. It grows very quickly in the open area and dominates degraded ecosystems (Kirkham 2004). The development of this species has become a major threat for plant and animal biodiversity in national parks.

Bukit Barisan Selatan National Park (BBSNP) is the third-largest conservation area in Sumatera covering about $3,568 \mathrm{~km}^{2}$. It is located in southwest Sumatera $\left(4^{0} 31^{\prime}-5^{\circ} 57^{\prime} \mathrm{S}, 103^{0} 34^{\prime}-104^{\circ} 43^{\prime}\right.$ E), which extends $150 \mathrm{~km}$ along the Bukit Barisan Range. The area of BBSNP spans across two provincial administrations, Lampung and Bengkulu. This national park contains some of the largest tracts of lowland forest remaining on Sumatera (O'Brien etal. 2004).

The expansion of M pdtatain relation to forest fragmentation has been happening in Bukit Barisan Selatan National Park (BBSNP). The development of $\mathrm{M}$ pdtata has dominated about 7,000 ha of BBSNP area (Master etal. 2013). This species grows very quickly in the open area and forest edges. Theinvasion of this species results in significant ecological consequences. M pdtata creeps and covers the area and blocks the development of seedling. It also climbs up the host trees or shrubs and may eventually kill them. Master $\notin$ al. (2013) found that area dominated by M pdtatahas lower diversity index than area where M. petata is not dominant. Mega faunas, such as elephant, are also found to avoid area where this liana is dominant. In the long run, the expansion of this type of invasive species may contribute to the extinction of other species (Clavero \& G arciaBerthou 2005).

Existence of M. pdtatain an area affects species conservation. Therefore, ecological aspects of this species need to be studied. To date, there is lack of information on the ecological aspects and ecophysiological characters of this species. Available information on this species so far includes the record on the invasive plants of the Pacific (Josekutty \& al. 2002), its natural distribution in certain area in the Pacific (Kirkham 2004) and its impact on the plant biodiversity in the invaded area (Master \& al. 2013). The information on the ecological and ecophysiological characters may provide scientific foundation in future management of this species. Therefore, this research investigates the population density and size of M pdtatain open and intact forests and its ecophysiological characters which may contribute to this species ability to invade a certain forest area.

\section{MATERIALS AND METHODS}

This study was conducted in Pemerihan Resort of BBSNP in the Lampung Province (Fig. 1). Pemerihan Resort is about 19,009 ha. This area was chosen as $\mathrm{M}$ pettata has started dominating several sites. However, compared with other areas in the BBSNP, such as Tampang and Way Haru Resorts, the development of M. patata in the Pemerihan Resort has not been as massive as in those two resorts. Therefore, this research may provide insight into earlier stage of the invasion of this species.

Early observation indicated that the proliferation of $\mathrm{M}$ pdtata might be enhanced by forest opening; therefore, ecological aspects of this species were studied by comparing its population structure in open/fragmented and intact forests. Intact forest is dominated by large trees, while open area is dominated by shrubs and smaller trees. These two areas have distinct microclimates. Light intensity in the two areas was observed by using solar radiation meter. Fifty (50) $5 \times 5 \mathrm{~m}$ plots were established in the open area where this species was dominant. 0 ther 50 plots were placed in the intact forest next to the open area. The number of $\mathrm{M}$ pdtata was counted and the stem diameter was measured at the $0.5 \mathrm{~m}$ from the plant base. In case that plant individual has climbed and covered shrub or tree canopy, the canopy projection of the affected shrubs or trees was quantified. The differences of light intensity and the population attributes between the two sites were analysed by employing Student's t-test. 


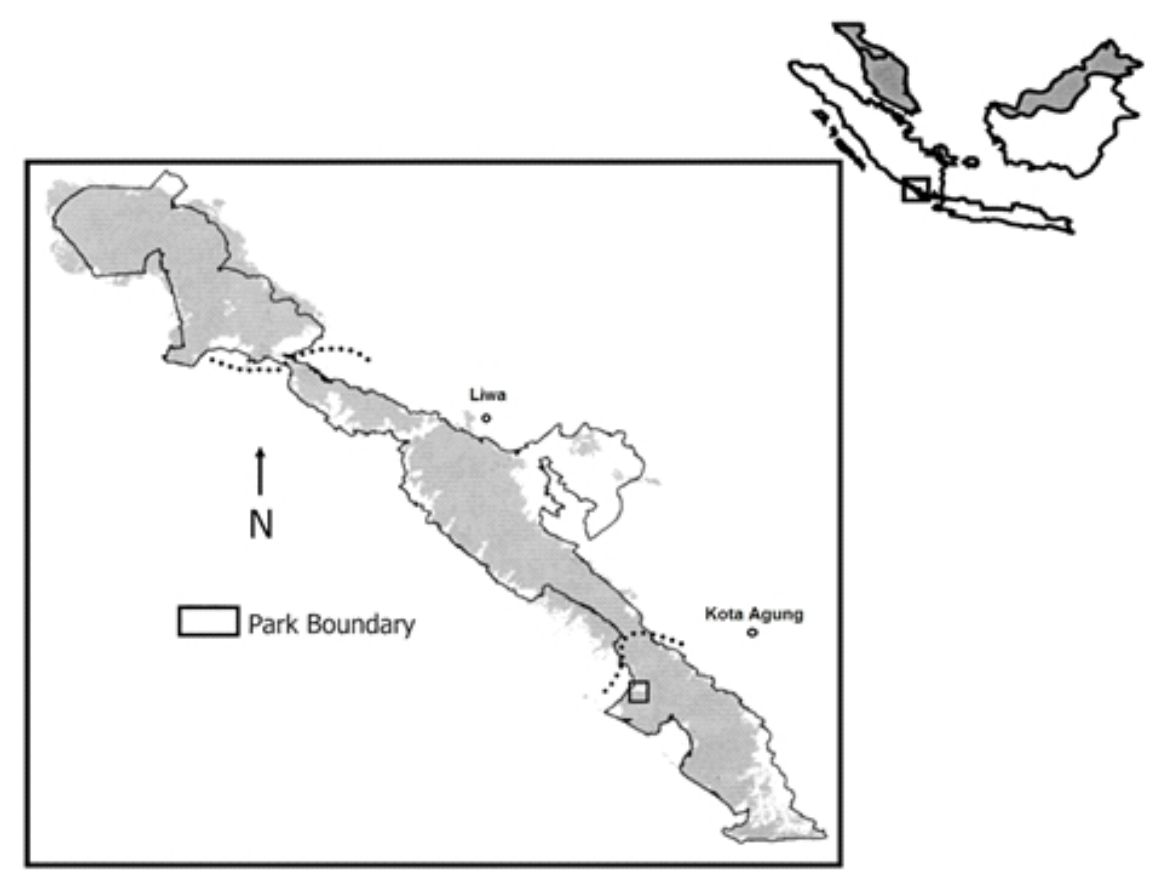

Figure 1. The location of Bukit Barisan Selatan National Park in southwest Sumatera (inset). The study site was at the Pemerihan Resort $(\square)$

Observation of M pettata coverage to its host when it climbs was approached by measuring the light intensity under the occupied canopy and above the canopy. The percentage of canopy coverage by M. patata to host's canopy was then counted by employing formula:

where:

$$
\text { Percentage of canopy coverage }=
$$$$
100 \text { - (LIUC/ LIAC) x } 100
$$

LIUC = Lightintensity under the canopy

LIAC = Light intensity abovethe canopy

Observed ecophysiological characters included Specific Leaf Area (SLA), wood density and xylem anatomy. Fifty (50) healthy leaves were taken from 50 individuals. Leaf area was then measured by analyzing the leaf images using a computer program called ImageJ (National Health Institute USA). Those leaves were then oven-dried at $70{ }^{\circ} \mathrm{C}$ for two days and were measured for their dry weight. SLA is the ratio of leaf area $\left(\mathrm{cm}^{2}\right)$ and dry weight $(\mathrm{g})$. Wood density was observed for 50 wood fractions from 50 individuals. After the volume of wood pieces was quantified, the wood samples were oven-dried at $70^{\circ} \mathrm{C}$ for two days and were measured for their dry weight. The wood density is the ratio between wood dry weight $(\mathrm{g})$ and wood volume $\left(\mathrm{cm}^{3}\right)$.
Fifty wood samples from 50 individuals above were also taken for xylem observation. Before they were observed, the wood samples were put in $70 \%$ alcohol. In the laboratory, the samples were transversally sectioned and then were observed under microscope. Pictures of the samples were taken. Diameter of the xylem vessels was measured using ImageJ software (National Health Institute USA). Vessel diameters of stems were divided into $10 \mu \mathrm{m}$ size classes. To determine the theoretical contribution of each vessel size class to the hydraulic conductance of the stem, vessel diameters were raised to the fourth power (Hagen-Poiseuille Law) (Tyree \& Zimmerman 2002). The Hagen-Poiseuille Law is based on the experiments by Hagen in 1839 and Poiseuille in 1840 which found that water molecules are stationary on the capillary wall and move faster in the centre of the capillary. Therefore, flow rate is proportional to the fourth power of the radius of the capillary (Tyree \& Zimmerman 2002). The relative contribution of each diameter class is the proportion of the sum of all the conduits raised to the fourth power. This sum reflects the capacity of stem to conduct water, which will consequently affect the ability of plants to grow faster. 


\section{RESULTS AND DISCUSSION}

The expansion of M pdtata has become a real problem for species conservation in the BBSNP area. Since it was established in early 1970s, M. pdtata has dominated approximately 7,000 ha of BBSN P area (Master $\&$ al. 2013). Satellite image showed that in 2002, M pdtatadominated area of about 6,393 ha. This area had become about 7,008 hain 2008 (TNBBS 2011). Area of BBSNP which will be dominated by $\mathrm{M}$. pdtatais likely to be wider in the future. In the Pemerihan Resort, where this study was conducted, the expansion of M. pdtata has just been occurring for the last few years. This showed that this species keeps spreading to all areas of BBSNP.

Light intensity between the two study sites differed significantly $(t=10.571 ; p<0.01)$. In the intact area, the light which went through the canopy and reached forest floor was about 171.26 lux. In the open area, the average light intensity was about 293.30 lux. This difference reflected the gradient of energy available for vegetation in these two different sites.

The average number of $\mathrm{M}$ pdtata in both study sites differed significantly $(\mathrm{t}=4.907 ; \mathrm{p}$ $<0.01$ ) (Fig. 2). In the open area, the average number of $\mathrm{M}$ pdtataper area was 4.46 individuals per $25 \mathrm{~m}^{2}$. In the intact area it was only $0.20 \mathrm{M}$ pdtata plants per $25 \mathrm{~m}^{2}$. The figure shows that $\mathrm{M}$ pettatapreferred an open and fragmented area.

This research indicated that forest opening enhanced the expansion of $\mathrm{M}$ pdtata As a fast growing species M pdtataquickly dominated the landscape and form a dense population. The number of $\mathrm{M}$ pdtatain the open areawas 20 times as many as that in the shaded area. The area openness provides a full sunlight, in which this condition is favoured by pioneer species (Whitmore 1989).

The domination of one species can also be indicated by the total basal area. This study found that total basal area of M. pdtata in the open area, i.e. $8.84 \mathrm{~cm}^{2}$ per $25 \mathrm{~m}^{2}$, was higher than $\mathrm{M}$. pdtataplants in the shaded area, i.e. 0.58 per $25 \mathrm{~m}^{2}$ $(\mathrm{t}=4.435 ; \mathrm{p}<0.01)$ (Fig. 3). This indicated that total accumulation of biomass of $\mathrm{M}$ pdtata was much higher in the open area than in the shaded area.

Disturbances, in this case forest clearing/ fragmentation, change the ecosystem dramatically (Hooper \& al. 2004) by affecting the availability of crucial resources, such as light, water and nutrients, in the area. Consequently, plants may respond differently to this gradient and ultimately this will determine which species will coexist (Brokaw \& Busing 2000). The differences in performance involve establishment, growth and survival. The success of $\mathrm{M}$. pdtata to dominate the area depended on their ability to exploit resources and adapt with the available environmental niches. As the development of this species was much better in the open area, the more forest fragments created more chances this species had to invade the forest area.

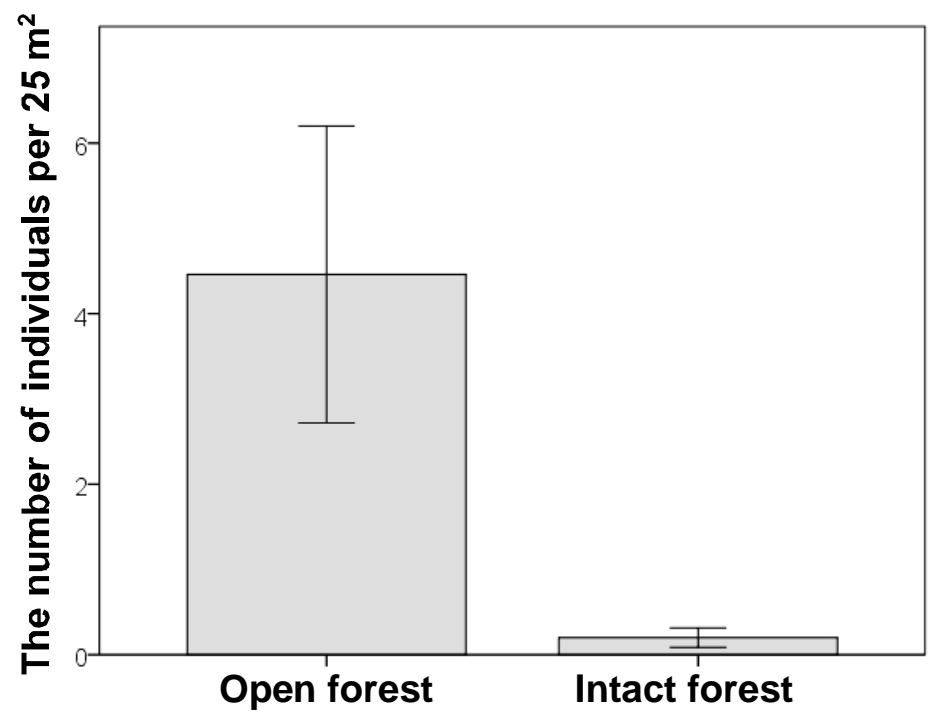

Figure 2. The number of individuals of M. patataper $25 \mathrm{~m}^{2}$ in the open and intact forest areas. Error bar indicates $95 \%$ confidence intervals 


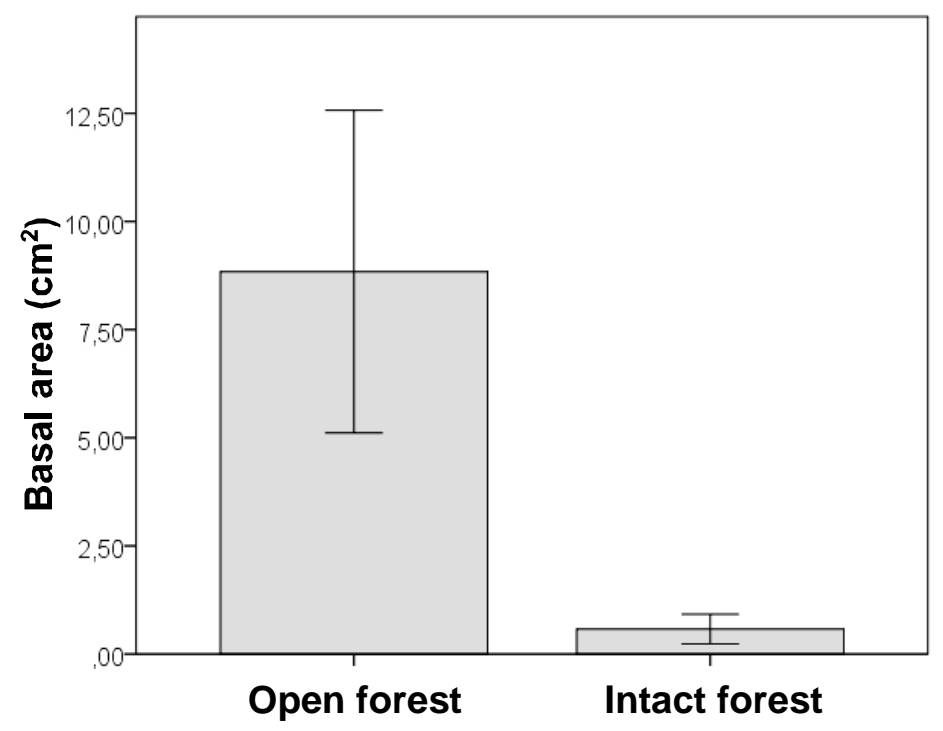

Figure 3. Total basal area of M. pdtata per $25 \mathrm{~m}^{2}$ in the open and intact forest areas. Error bar indicates $95 \%$ confidence intervals

Table 1. Thepercentage of canopy density of trees/ shrubs occupied by M pdtatain the two sites of observation

\begin{tabular}{rcccc}
\hline & \multicolumn{2}{c}{ Open forest } & \multicolumn{2}{c}{ Intact forest } \\
\cline { 2 - 5 } & $\begin{array}{r}\text { Canopy diameter } \\
(\mathrm{m})\end{array}$ & $\begin{array}{c}\text { Percentage of canopy } \\
\text { coverage }\end{array}$ & $\begin{array}{c}\text { Canopy diameter } \\
(\mathrm{m})\end{array}$ & $\begin{array}{c}\text { Percentage of canopy } \\
\text { coverage }\end{array}$ \\
\hline 1 & 4 & 86.79 & 3 & 69.20 \\
2 & 3 & 77.47 & 7 & 58.37 \\
3 & 4 & 72.48 & 4 & 86.40 \\
4 & 4 & 80.96 & 7 & 86.25 \\
5 & 3 & 74.92 & 4 & 82.71 \\
6 & 4 & 74.13 & 2 & 86.75 \\
7 & 3 & 68.25 & 3 & 79.45 \\
8 & 4 & 75.58 & 5 & 81.58 \\
9 & 3 & 74.25 & 7 & 58.80 \\
10 & 4 & 77.03 & 4 & 86.85 \\
\hline & Average & 76.19 & & 77.63 \\
\hline
\end{tabular}

Canopy of the host plants occupied by $\mathrm{M}$ petata had high canopy density. The average percentage of canopy coverage of $\mathrm{M}$. pdtata occupied trees/ shrubs was $76.19 \%$ in the open area and $77.63 \%$ in the shaded area (Table 1). In comparison, surrounding trees/ shrubs which were not occupied by $\mathrm{M}$. petata had only about 30-50\% canopy coverage. This showed that $\mathrm{M}$. petatahad covered the host canopy severely, which subsequently might affect the growth of those trees or shrubs.
Wood density of $\mathrm{M}$. patata was $0.6 \mathrm{~g} / \mathrm{cm}^{3}$ (Table 2). In comparison, the value of water density as a standard at $4{ }^{\circ} \mathrm{C} F$ was $1 \mathrm{~g} / \mathrm{cm}^{3}$. Hence, the value of wood density of $M$ pedtata was categorized low. The value of SLA of $M$ pdtata was $160.33 \mathrm{~cm}^{2} / \mathrm{g}$ (Table 2). Compared with other climbing species, this value was very high. Observations on Fregindia excesa and Raphidqphora australasica showed that their SLA values were $9.74 \mathrm{~cm}^{2} / \mathrm{g}$ and $16.36 \mathrm{~cm}^{2} / \mathrm{g}$, respectively (Yansen 2012). 
Table 2. Specific leaf area and wood density (with standard errors) of M pdtata

\begin{tabular}{clc}
\hline No & Observed characters & Value \pm SE \\
\hline 1 & Specific leaf area & $160.30 \pm 4.80 \mathrm{~cm}^{2} / \mathrm{g}$ \\
2 & Wood density & $0.60 \pm 0.03 \mathrm{~g} / \mathrm{cm}^{3}$ \\
\hline
\end{tabular}

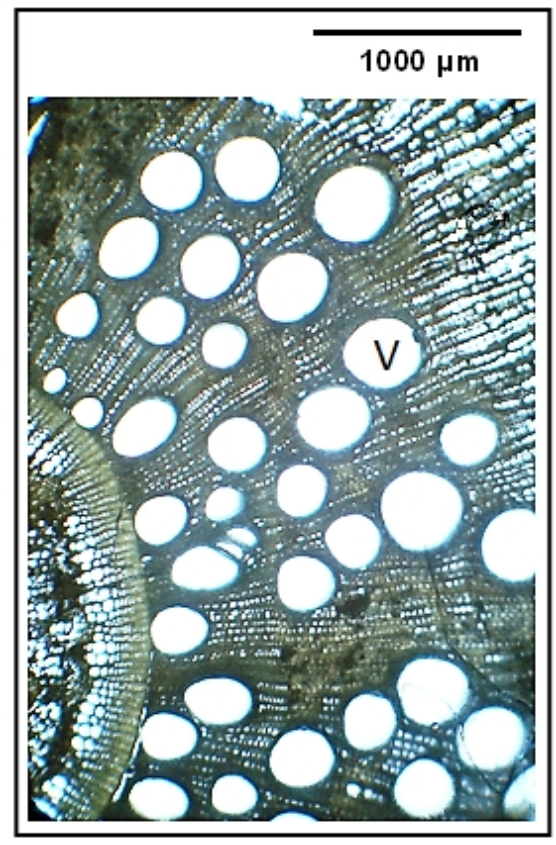

Figure 4. The transverse section through stem xylem tissue of $\mathrm{M}$ pdtatashowing its vessels (V)

SLA is commonly found to have a significant negative correlation with leaf thickness (Vile $\&$ al. 2005). Leaves with high SLA (i.e. low leaf mass area/ LMA), are usually thinner and have low tissue density and low leaf construction cost (O sunkoya \&al. 2010). On the other hand, thicker leaves (i.e. lower SLA/ higher LMA) may correlate to longevity of leaf life span (Chabot \& Hicks 1982; Putz \&al. 1995; Mediavilla \&al. 2001), high construction cost (Westoby $\notin$ al. 2002) and more drought tolerance (Salleo \& Lo Gullo 1990; Mediavilla \& al. 2001). The leaf turn-over of $\mathrm{M}$. pettata is fast; hence it can grow very quickly in a short time.

The average diameter of the $\mathrm{M}$. pdtata xylem vessels was $292 \mu \mathrm{m}$ (Fig. 4). The vessel size class distribution showed that about $40 \%$ of vessels in M. pettata stem had a diameter greater than 300 $\mu \mathrm{m}$. However, over $300 \mu \mathrm{m}$ vessels in fact provided about $70 \%$ of the hydraulic conductance (Fig. 5). The average vessel diameters of $\mathrm{M}$. pdtataare also higher than several climbing plants studied by Fisher $\notin$ al. (2002) and Yansen (2012) (Table 3). These findings indicated that the ability of $\mathrm{M}$. pdtata stem to conduct water was high which significantly contributed to the ability of this species to grow faster.

The ecophysiological characters of M. pdtata show that this species does not invest too much on structural strength and it tends to grow faster. This indicates that this species is categorized as ruderal (Grime 2002) which dominates the disturbed areas but it will not persist in the long term when the forest area becomes more intact and shaded. Therefore, an ecological engineering is needed to reduce the domination of this species in thearea. 


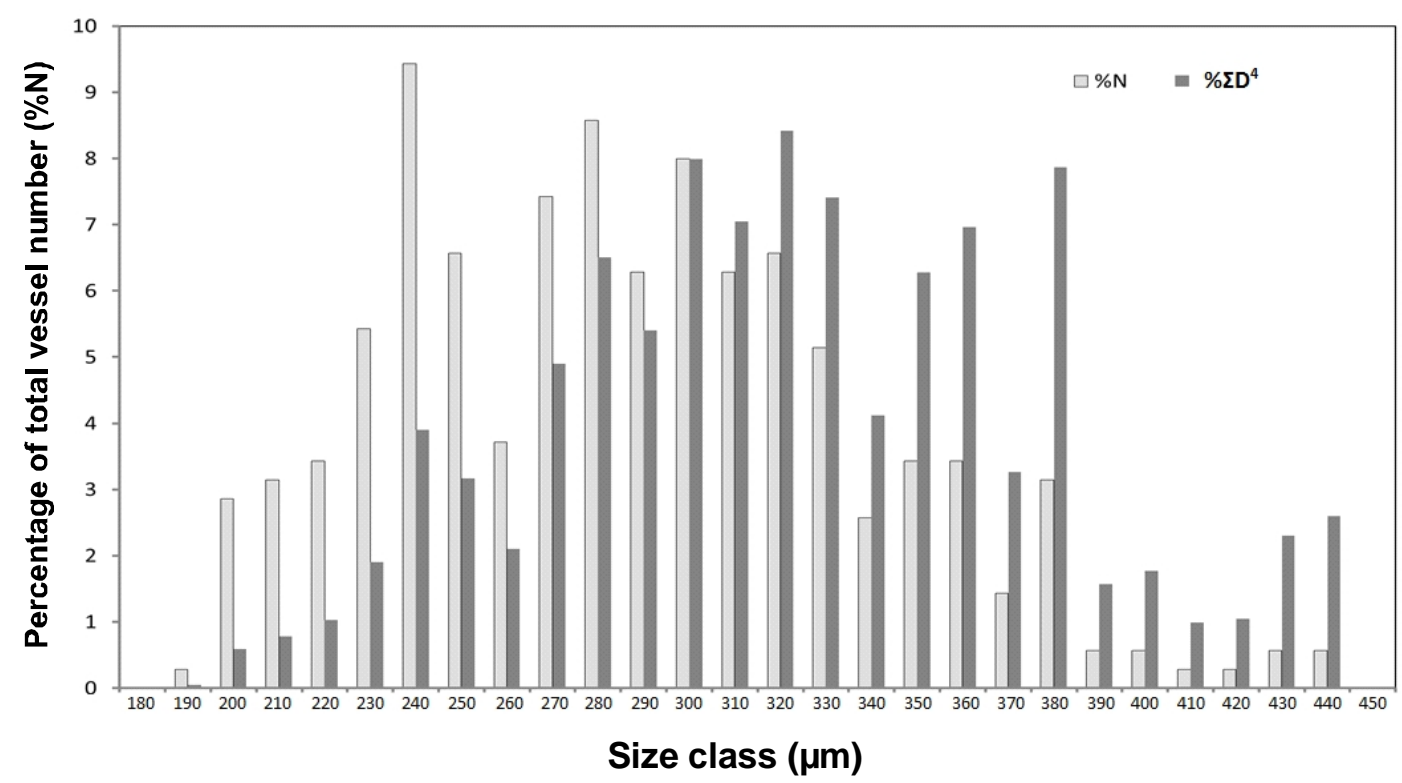

Figure 5. Distributions of stem vessel diameters of $\mathbf{M}$ pdtatain $10 \mu \mathrm{m}$ size classes. The graphs show the number of vessels of each size class as a percentage of the total vessel number $(\% \mathrm{~N})$ and the theoretical contribution of each size class to hydraulic conductance $\left(\Sigma \mathrm{D}^{4}\right)$ of the stem. The hypothetical contribution to conductance was calculated by summing the diameters of vessels in each size class to the fourth power (Hagen-Poiseuille Law) (Tyree \& Zimmerman 2002).

Table3. Average diameter of vessels of several climbing rattans (1-6), climbing pandanus (7) and climbing aroid (8) compared to currently studied species (9) (Fisher eal. 2002; Yansen 2012).

\begin{tabular}{|c|c|c|}
\hline No. & Species & Average diameter of vessels $(\mu \mathrm{m})$ \\
\hline 1 & Calamusinsignis & 213 \\
\hline 2 & Daemmorqpshystix & 243 \\
\hline 3 & Kathalsia ehinomera & 380 \\
\hline 4 & Korthalsia nigida & 532 \\
\hline 5 & Kothalsia rostrata & 205 \\
\hline 6 & Plectocomia dongate & 458 \\
\hline 7 & Frejaintia excedsa & 150 \\
\hline 8 & Rhaphidqphora australasica & 170 \\
\hline 9 & Merremia pettata & 292 \\
\hline
\end{tabular}

\section{CONCLUSIONS}

The differences in population attributes of $\mathrm{M}$ pdtatain the open and intact forests indicated that the expansion of this species was enhanced by forest fragmentation. It grew quickly in open area. The ecophysiological characters of M pdtata also supported the ability of this species to become a strong invader and competitor in a short-time. If more forest fragments were created, this species had more chances to invade the forest area. As the domination of this species had significant ecological consequences, a long term observation on population and growth dynamics was essential. Therefore, the application of appropriate ecological approaches to overcome the domination of this species could be applied.

\section{ACKNOWLEDGEMENTS}

This research was fully funded by the Directorate of Higher Education, the Ministry of Education and Culture, Republic of Indonesia, in which the authors thanked the institution. The authors also thanked Candra Lumbagaol and Ahmad Ritonga for their assistance in the field. This project was conducted in Bukit Barisan Selatan National Park and we thanked the BBSNP office that had granted permit to access the conservation area. 


\section{REFERENCES}

Brokaw N, Busing RT. 2000. Niche versus chance and tree diversity in forest gaps. Tree 15:183-88.

Brown JH. 1984. On the relationship between abundance and distribution of species. Am Nat 124: 255-79.

Bchabot BF, Hicks DJ. 1982. The ecology of leaf life spans. Ann Rev Eco Sys 13: 229-60.

Clavero M, Garcia-Berthou E. 2005. Invasive species are a leading cause of animal extinctions. Trends Eco Evo 20:110-15

Connell, JH. 1978. D iversity in tropical rainforest and coral reefs. Science 199:1302-10.

D enslow JS. 1987. Tropical rainforest gaps and tree species diversity. Ann Rev Eco Sys 18: 431-52.

Fisher JB, Tan HTW, Toh LPL. 2002. Xylem of rattans: vessel dimensions in climbing palms. Am J Bot 89: 196-202.

G rime JP. 2002. Plant Stratejes andV Vegtation Prowses New York (US): John Wiley and Sons.

He F, Legendre P, LaFrankie JV. 1997. D istribution patterns of tree species in a Malaysian tropical rainforest. J Veg Sci 8: 105-14.

He F, Gaston KJ. 2000. Estimating species abundance from occurrence. Am Nat 156: 553-59.

Hellmann JJ, Byers JE, Bierwagen BG , D ukes JS. 2008. Five potential consequences of climate change for invasive species. Con Bio 22: 534-43.

Hooper ER, Legendre P, Condit R. 2004. Factors affecting community composition of forest regeneration in deforested, abandoned land in Panama. Ecology 85: 3313-26.

Janzen DH. 1970. Herbivores and the number of tree species in tropical forest. Am Nat 104: 501-28.

Josekutty PC, Wakuk EE, Joseph MJ. 2002. Invasive/ weedy angiosperms in Kosrae, Federated States of Micronesia. Micronesia Supp 6: 61-5.

Kirkham WS. 2004. Situating the Meremiapdtatainvasion in Samoa. G eo Rev 94:218-28.

Master J, Tjitrosoedirdjo SS, Qayim I, Tjitrosoedirdjo S. 2013. Ecological impact of Meremia pettata (L.) Merrill invasion on plant diversity at Bukit Barisan Selatan National Park. Biotropia 20:29-37.
Mediavilla S, E scudero A, Heilmeier H. 2001. Internal leaf anatomy and photosynthetic resource-use efficiency: interspecific and intraspecific comparisons. TreePhys 21:251-59.

O'Brien TG, Kinnaird MF, Nurcahyo A, Iqbal M, Rusmanto M. 2004. Abundance and distribution of sympatric gibbonsin a threatened Sumateran rain forest. IntJ Prim 25: 267-84.

Osunkoya O0, Bayliss D, Panetta FD, Vivian-Smith G. 2010. Leaf trait co-ordination in relation to construction cost, carbon gain and resource-use efficiency in exotic invasive and native woody vine species. Ann Bot 106:371-80.

Putz FE, Romano G B, Holbrook NM. 1995. Phenology of epiphytic and tree-phase strangler figs in a Venezuelan palm savannah. Biotropica27:183-9.

Salleo S, Lo Gullo MA. 1990. Sclerophylly and plant water relations in three Mediterranean species. Ann Bot 65:259-70.

Taman Nasional Bukit Barisan Selatan. 2011. Ancaman dan penanganan tanamaninvasif speciesmantangan(Meremia pdtata) di TamanNasional Bukit Barisan Sdatan Kota Agung.

Tyree MT, Zimmerman MH. 2002. XylemStructureand the Ascentof Sap Berlin (DE): Springer-Verlag.

Vila M, Weiner J. 2004. Are invasive plant species better competitors than native plant species? Evidence from pair-wise experiments. 0 ikos 105: 229-38.

Vile D, G arnier E, Shipley B, Laurent G, Navas ML, Roumet C, Lavorel S, D iaz S, Hodgson JG, Lloret F, Midgley GF, Poorter H, Rutherford MC, Wilson PJ, Wright IJ. 2005. Specific leaf area and dry matter content estimate thickness in laminar leaves. Ann Bot 96: 1129-36.

Westoby M, Falster DS, Moles AT, Vesk PA, Wright IJ. 2002. Plant ecological strategies: Some leading dimensions of variation between species. Ann Rev Eco Sys 33: 125-59.

Whitmore TC. 1989. Canopy gaps and the two major groups of forest trees. Ecology 70:536-8.

Yansen. 2012. Changing connections: ontogenetic ecophysiology of secondary hemi-epiphytic vines. $\mathrm{PhD}$ thesis Townsville(AU):James Cook University. 